\title{
Islamic and Conventional Economics - Dialogue and Ethics
}

\author{
Muhammad Anas Zarqa ${ }^{(1)}$ \\ Senior Advisor, Shura Sharia Consultancy, Kuwait
}

\begin{abstract}
Dialogue and intellectual trade between Islamic economics and conventional economics has been active and mutually beneficial for more than 40 years. I present some concrete examples of this in the current paper. I then assess recent calls for a complete break of Islamic economics with conventional economics, and find them clearly inconsistent with Islam's actual approach to culture and institutions in preIslamic Arabia. The Islamic approach shuns blanket acceptance or rejection of any piece of human knowledge, and calls for detailed case by case assessment, then adoption, rejection, or acceptance after modification. The Islamic approach also insists on severability wherever possible, to salvage good parts from a bad whole. One particular argument for total break from conventional economics, is its assumption of selfishness of economic agents. I demonstrate that this is an overreaction by giving specific examples of Muslim jurist's nuanced view of selfishness (or self-interest): when acceptable, when discouraged, and when completely prohibited. I conclude that from an Islamic point of view, a break with conventional economics is not justified. Continued engagement with conventional economics is necessary and mutually beneficial, provided due attention is given to: (a) the non-selfish sectors, and (b) to behavioral and institutional reforms. Finally, the paper comments on ethics in conventional economics and Islamic economics.
\end{abstract}

Keywords: Islamic economics, Economic methodology, Comparative economic systems.

JEL Classification: B4, B59, P4, P5

KAUJIE Classification: F5, G2, H21, H22, H67

(1) The author is grateful to Shura for consistent support. Opinions expressed are his personal. 


\section{The Three Conceptual Components of Economics}

It is useful in discussions on methodology to distinguish three conceptual components of any economics, regardless of its ideological hue:

(a) The positive component (descriptive/ analytical): This is the repository of the positive statements of "what is", comprising descriptions of reality and relationships of causes and effects among variables.

(b) The ethics component (may also be called the normative or system component): This is the conceptual repository of normative elements relevant to economics, such as values, the do's and don'ts, goals and institutions deemed essential to the system. The worldview is also included here for brevity. Though, in a more detailed study it is best considered a separate component.

(c) The policy component: This comprises ways of using positive means (from the positive component) to reach desirable goals (from the ethics component).

Policy, is a joint venture between the positive and normative components in economics.

\section{Intellectual Trade between Islamic and Conventional Economics}

Islamic economics (IE) in its modern form started more than 40 years ago, with the first international conference on Islamic economics, 1976, held at Makkah al-Mukarramah. IE's academic activities always included active dialogue with conventional economics (CE).

That intellectual trade has been mutually beneficial, because each side enjoys a distinct comparative advantage. Venues for this dialogue include academic journals (this journal being the earliest pioneer), many international conferences, and several institutions such as the IEI (Islamic Economics Institute, KAU), IRTI, and INCIEF, to name a few.

Conventional economics has a comparative advantage in its positive component, i.e., the accumulated human stock of descriptive statements on causes-effects and tools of analysis and testing.
IE's comparative advantage lies in its ethics component grounded on revealed knowledge, i.e., the Sharī'ah, comprising the Holy Qur'ān and authentic sayings and actions of the Prophet (may the peace and blessings of Allah be upon him), which are very well preserved, and extensively related to economic matters. Based on that revealed knowledge, a very large body of a systematic scholarly jurisprudence (fiqh) has grown.

For instance, Islam has explicit rules and principles about monopoly, price ceilings, public supervision of markets (al-hisbah), contracting rules, financial recording and dispute resolution, wealth concentration and redistribution policies (in addition to zakāh), extended family financial obligations, disposition of public funds, and common access to natural resources.

Islamic economics shares with conventional economics its human sources of knowledge (introspection, observation, logical reasoning, modelling, testing, etc.), but has in addition a unique source comprising Sharī ah and fiqh.

Revealed knowledge is not meant to replace the human acquired knowledge ('aql), but to guide it. However, having two sources of knowledge opens the possibility of their disagreement on a particular issue, and thus, signals the need to review and resolve the conflict (which, Sharī ah scholars assert, can only be apparent not real).

A concrete example of this mutually beneficial professional dialogue can be seen in the position statement of the International Association for Islamic Economics (IAIE), issued in late 2008, in the aftermath of the global financial crisis (IAIE, 2009). The complete statement is given in the appendix. Other more detailed examples are: "Towards an interestfree Islamic economic system" (W. M. Khan, 1989); "Islamic finance: theory and practice" (Mills \& Presley, 1999); and "Allocation of investment in an Islamic zero-interest-rate economy" (M. Anas Zarqa, 2017). All of these three relate to different aspects of the prohibition of interest on loans. A fourth example is al-Suwailem's "Hedging in Islamic finance" (2006), which is an original contribution that uses game theoretic tools to explicate the prohibition of gambling and gharar in exchanges, and to suggest practical solutions. 
It is not surprising that much of the modern literature in Islamic economics and its dialogue with conventional economics still relates to the prohibition of interest on loans, a major Sharī'ah rule that clearly contradicts common notions in conventional economics. I'll argue later that a refocus of Islamic economics on other issues is overdue.

\section{Recent Calls for a Complete Break with Conventional Economics}

Some writers on Islamic economics are becoming increasingly critical of the direction IE took in the last few decades, calling for total break with conventional economics, and a fundamental revision of focus for IE. Asad Zaman (2013) is the most eloquent protagonist of this stance.

Calls for breaking with conventional economics, especially with the Neoclassical school (NC), are often based on two arguments, one related to values, the other related to the "positive component" of conventional economics.

The first argument was well summarized by Akram Khan (who doesn't share it):

(a) [to] reject everything that the conventional economics offers since the basic assumptions and worldview of conventional economics is different from those of the Islamic economics.

(b) The idea was to develop a brand-new branch of knowledge, solely based on Islamic primary sources [Numbering added]. (M. A. Kahn, 2018, p. 43)

To logically justify a break, (a) is insufficient; one must further assume that CE's tools of analysis, its assumptions, and its policy conclusions, are all uniquely defined by its "value component". That is, one must assume that an economics with a different "value component" must logically have different tools of analysis, assumptions, and policy conclusions.

The second argument highlights the positive shortcomings of conventional economics; especially its excessively simplifying assumptions regarding the behavior of economic agents (e.g. complete rationality and unqualified selfishness), which are often used to support the capitalist worldview and to assert optimality of free market outcomes.

\section{Is A Break with Conventional Economics Consistent with the Islamic Sharī' ah Approach?}

A blanket acceptance or rejection of a piece of human knowledge is not actually consistent with Sharī'ah's approach, which is analytical, case by case, and just. It calls for careful assessment, then adoption, modification, or rejection. It also calls for severability wherever possible, to salvage good parts from a bad whole.

Let us now review some concrete examples.

\subsection{Pre-Islamic Poetry}

(a) The Prophet (may the peace and blessings of Allah be upon him) said: "Some poetry expresses wisdom" (al-Bukhari, 1422H, 8:34, hadith no. 6145).

(b) The Prophet (may the peace and blessings of Allah be upon him), when important news was delayed, would quote a line from pre-Islamic poet Tarafah ibn Al 'Abd: " He may carry the news to you, one you have not provided for" (alShaibani, 2001, 40:24, hadith no. 24023).

Hadith (a) calls attention to the fact that some poetry expresses wisdom. The bulk of Arabic poetry at the time was composed by polytheist Arabs during the jāhiliyyah (period of ignorance) in pre-Islamic Arabia. From an Islamic point of view, it was a mixed baggage comprising many good and many bad items. Hadith (a) highlights a particularly valuable item deserving Muslims' adoption: wisdom.

Hadith (b) is an application of (a), where the Prophet (may the peace and blessings of Allah be upon him), quoted a line of wisdom from the poet Tarafah, advising optimism when eagerly waiting for news.

The special significance of hadith (b) for our discussion becomes clearer when one considers the biography of the quoted poet. Tarafah was a young genius poetic widely quoted and acclaimed at his time. Several of his wise lines became proverbs, including the line quoted above. He was also a playboy who squandered his inherited wealth, literally on "wine, women, and song". Even by the permissive standards of the jähiliyyah, he was rebuked and ostracized by his clan. Undeterred, he poetically 
asserted there is no point in depriving oneself of pleasures now, for soon we all shall turn to dust; there is no afterlife.

All this and more he explicitly and poetically expressed in a renowned long poem of more than 100 couplets which contains the line of wisdom salvaged and quoted by the Prophet (may the peace and blessings of Allah be upon him).

\subsection{Institutional and Other Pre-Islamic Heritage}

Pre-Islamic religious beliefs and worldview (polytheism, paganism), were rejected and replaced by Islamic ones. However, the unadulterated beliefs and rituals inherited from Prophets Abraham and Ishmael (Ibrahim and Isma'il, peace be on both), such as the sanctity of the holy Ka'bah and the Makkan sanctuary, and most rituals of the pilgrimage (hajj) were retained.

Some contracts and institutions were accepted in Islam with little or no modification, because they were consistent with the Sharíah. For instance, the mudārabah contract "has been practiced during jāhiliyyah and approved in Islam" (Ibn Rushd, 1995, 2:191).

Similarly, the pre-Islamic contract of salam (forward sale of future crops) in Madinah was accepted, but with Islamic corrections. Other types of thenprevalent forward sales, e.g., of future offspring of domestic animals were strictly prohibited, because they involved excessive gharar (contractual uncertainty).

Similarly, two important ancient institutions were approved with some modifications:

- The custom of paying blood money (diyah), as compensation for unintentional manslaughter, and

- The 'ãqilah system; an extended tribal collective social insurance to help the unintentional killer pay the blood money, whose sum was beyond the means of ordinary people.

Each example above also serves to dispel the assertion that a different worldview or value system such as that of pre-Islamic (jāhiliyyah), must have institutions and policy conclusions different from Islamic ones.

\subsection{Prominent Juristic Views}

\subsubsection{Al-Ghazali and Greek Philosophy}

Al-Ghazali (b. 1058CE/450H) was an outstanding polymath of his time: top jurist (faqih), top methodologist (ușūl al-fiqh), top philosopher, and top șüfi (Islamic mystic).

In his lucid intellectual autobiography al-Munqidh min al-dalāl [The Deliverer from going astray] (2013), he analyzed the response of intellectuals of his time to Greek philosophy which comprised diverse sciences. After a thorough study, al-Ghazali divided these sciences into different types, two of which are relevant to this discussion.

The first type, which included mathematics, geometry, astronomy, and logic, were based on demonstrable proofs or observation, which any knowledgeable person should acknowledge. The second type were metaphysical speculations grounded in Greek polytheist religion, which are unacceptable in Islam.

Al-Ghazali lamented the response of two misguided groups of intellectuals of his time. The first was so impressed with the first type of Greek philosophy, that they assumed all its sciences were equally sound and imitable, including its metaphysics. They were led astray from Islam by blind imitation.

The second group, which al-Ghazali called the "ignorant friends of Islam", thought that supporting Islam required denial of all sciences attributed to Greek philosophy, even denying their statements about eclipses, and claiming these to be against religion. When such claims reached persons who knew by solid proofs the truthfulness of the statements, they came to believe that Islam is based on ignorance and denial of solid proofs. It increased their love of philosophy and hate of Islam. Al-Ghazali (2013) says: "What a great crime against religion: to claim that you support Islam by denying these sciences" ( $p$. 66).

\subsubsection{Al-Qaradawi and Modern Social Sciences}

Al-Qaradawi, is a prominent contemporary Sharīah scholar and prolific author. He wrote in his foreword to an Islamic psychological study: 
We may have an "Islamic school in psychology", and "an Islamic school in sociology", etc. Expressions which I prefer to "Islamic psychology" and "Islamic sociology". I do not recommend throwing out what the West has achieved in these sciences and starting from zero... we may benefit from Marx in economics, Durkheim in sociology and Freud in psychology; for not everything they wrote is false nor is it sacrosanct. What is important is to keep our right to criticize and the right to choose according to our own standards. (al-Qaradawi, 1995, pp. 12-13)

Thus, we can conclude that the Shari' ah approach calls for a just, case by case, detailed assessment, giving explicit credit to potentially useful human knowledge, regardless of the identity, religious beliefs, or worldview of its generators. It is also efficient, not wasting useful knowledge.

\section{Is the Assumption of Selfishness Acceptable?}

A second argument for a break with conventional economics, especially with the Neoclassical school, is its simplifying assumption regarding selfishness of economic agents.

Selfishness is indeed an important part of economic reality, but not the only important part. Real humans have several other non-pecuniary and moral motivations, in addition to the selfish motivation.

Selfishness however is a very useful simplifying assumption to help us analyze and understand complex economic reality. Assumptions, as tools of analysis, are generally unavoidable in economic theorizing, to filter out myriads of details and focus on few variables.

The Holy Qur'ān acknowledges the power of selfinterest, as it appeals not only to humans' higher motives, but also and repeatedly to their self-interest, by promising Divine reward in the hereafter for those who follow its injunctions, and dire punishment to others (Qur'ān, 2:272; 41:46).

Jurists assess selfish behavior in various contexts, deriving appropriate rules for each. They note the permissibility of selfishness (or self-interest) in pecuniary exchanges, which they call "stingy exchanges". They state that the general rule for these exchanges is that: "exchanges or trades are based upon greed/selfinterest and bargaining" (IIFA, 2013, 21:9).
It is noteworthy that the Sharī ah and fiqh not only tolerate the assumption of selfishness when needed, but require it in certain situations.

(a) In judicial process, the Prophet Muhammad (may the peace and blessings of Allah be upon him) disallowed the testimony by a servant in favor of members of the household, but accepted a servant's testimony to nonrelated parties (al-Sijistani, 2009, 5:452, hadìth no. 3600).

(b) Jurists assert, by analogical reasoning, that a judge may not accept the testimony of a son in favor of his father, or a husband in favor of his wife, and vice versa (al-Zuhaili, 2012, 6:486487).

(c) The default ruling in fiqh is to disallow the same person to be an agent to both parties of an exchange, seller and buyer, because of potential conflict of interest. However, several schools of fiqh, including the Hanafĩ and Hanbalī schools, grant an exception to a father or grandfather to effect a sale or purchase between himself and his minor child or grandchild. Innate mercy and love, they assume, would prevent him from acting selfishly against the financial interest of his child (MAIASK, 1983, 14:194-195).

In the above three cases, the potential presence of selfishness (or self-interest) was the problem. The remedy was to assume selfish behavior in order to protect innocent parties.

(d) Muslim jurists also noted other cases where the absence of selfishness (or self-interest) may hurt the interests of weak parties in exchange, and suggested suitable remedies.

The default rule in most schools of figh is that mere overcharging is not sufficient to permit an aggrieved party to rescind a purchase, unless coupled with misrepresentation by the seller. An exception, where mere overcharging is sufficient to rescind a purchase, is granted to three entities: an orphan, a waqf, and the public treasury (bayt $a l-m \bar{a} l)$. The reason being that transactions of all three are effected through their legal representatives who often lack the self-interest to diligently avoid being overcharged. (Mustafa A. alZarqa, 1998, pp. 469-470 \& 1021-1022; Majallah al-Ahkam al-'Adliyyah, Article 356). 
Hence, we can conclude that selfishness/self-interest is permissible and judicially enforceable in pecuniary exchanges, but is not deemed a virtue. This is the best description I can give of the Shari ah position regarding self-interest. Non-selfish behavior for the sake of Allah is highly praised (and amply rewarded), but is not mandatory. Greed in the sense of single-minded pursuit of self-interest and wealth, is condemned. Acting selfishly in a fiduciary capacity (e.g. a judge, a ruler, a trustee, a public servant, a witness) is a crime and a grave religious sin.

\section{An Overdue Major Reform: To Refocus Islamic Economics}

We need to distinguish two sectors in any economy: the selfish exchange sector which is the major domain and focus of conventional economics. Most of the Shari' ah rules about pecuniary exchanges (fiqh al-mu 'ámalāt) relate to that sector. The remainder of the economy comprises the non-selfish sector, where actions are driven mainly by non-selfish motivations.

The non-selfish sector includes governmental, cooperative, and non-binding reciprocal exchanges and transfers, within the family and among relatives, neighbors, and friends. Note that even within the selfish sector, all fiduciary activities, where an agent is legally required to act in the best interest of another party, selfish actions are criminalized.

Clearly, activities of the non-selfish sector are extensive, have a big impact on human economic and other welfare, and have received much attention in Islam and other religions. Yet, this sector has received little analysis and is largely absent from reform proposals in both CE and IE. This probably led some economists to view the IE/CE dialogue as a distraction from the non-selfish sector and more worthy issues; or worse, as a dressed up materialistic worldview in Islamic garb. The best correction, they concluded, is a complete break with conventional economics. This, I think, is an unjustified overreaction.

A fully justified and overdue reaction to the past neglect of the non-selfish sector is to refocus Islamic economics towards a new balanced agenda. This should be done parallel with, not instead of, continued dialogue and exchange between IE and CE.

\section{Ethics in Economics}

In his lead paper, Reardon (2019, pp. 68-69) argued for restoring ethics to its rightful place in any reformed economics. I fully agree, and add the following points.

Ethics can be expressed directly in the form of a moral preference of one action or state over another; or indirectly in numerous other forms, including statement of goals.

Welfare economics within the neoclassical school, engaged for about half a century some of the most brilliant minds, who pursued the holy grail of a valuefree economic criterion to prefer one economic situation or policy over another.

By the 1940's it became clear that there can be no such criterion. A new welfare economics emerged, based on acknowledging the impossibility of formulating an ethics-free preference criterion. We have to import "from outside of positive economics a social welfare function appropriate to a given set of ethical norms" (Samuelson, 1967, p. vii).

Robbins, explained the matter more clearly:

For you cannot build prescriptions on a mere knowledge of positive facts, however systematized and comprehensive. You need a goal as well - a general objective, a criterion of the expected results of action. It is all very well to know how the world works, why certain relations emerge in certain conditions ... But unless you have some test whereby you can distinguish good from bad, desirable consequences from undesirable, you are without an essential constituent of a theory of policy. You are like the captain of a ship equipped with charts and compasses and all the means of propulsion and steering, but without an assigned destination. A theory of economic policy, in the sense of a body of precepts for action, must take its ultimate criterion from outside economics. (Robbins, 1952, pp.176-77)

This is equally true in all sciences, including hard ones like physics: "Science, however, cannot create ends and, even less, instill them in human beings; science, at most, can supply the means by which to attain certain ends. But the ends themselves are conceived by personalities with lofty ethical ideals" (Einstein, 1950, p. 124). 
If economics adopts the motto "science for science's sake", policy (using positive science to achieve goals) will no longer be part of economics. Economics thus can set itself free from ethics at the cost of becoming useless.

The motto "science for science's sake" however is definitely unacceptable in Islamic worldview, which favors science only in the service of human welfare.

Policy then remains an essential part, even arguably the raison d'etre of economics, as it is in other sciences. In this wider and more realistic framework, values or ethics have a permanent seat next to positive knowledge in formulating policies. Put differently, policy is necessarily a joint venture between the positive and normative components in economics.

\section{Accommodating Ethics}

As economics cannot run away from ethics, it has to accommodate it. But which ethics? There are many ethical systems (-isms), and even more ethical preferences in specific instances.
The Qur'ān asserts that Allah, the All-knowing, is the only source of true ethics. He sent them to humanity through His prophets. There are many false sources, the Qur'ān asserts, including: personal desires, enmity or affection towards others (even when justified), false deities and false leaders.

Islam's ethical system has a small mandatory core of principles and rules which are binding on everybody (fard or wäjib). All else falls in a much larger voluntary range, where extra rewards are earned by the ambitious, but no penalty is imposed on the modest.

Basic ethical principles are similar in Judaism and Christianity and Islam; a fact mentioned in the Qur'ān more than once. Several of these principles are also shared by people of other faiths, as well as many non-religious persons. Thus, there is a wide scope for theorizing, teaching, and policy formulation based on a common denominator of ethics that have global appeal. 


\section{References}

al-Bukhari, Muhammad bin Ismail. (1422H [2001]). Sahih al-Bukhari. Beirut: Dar Tawq al-Najah.

Einstein, A. (1950). Out of My Later Years. New York, USA: Philosophical Library.

al-Ghazali, Muhammad bin Muhammad. (2013). AlMunqidh min al-dalāl wa al-Mufsih bi al-Ahwal [The Deliverer from going astray and The Explanation of the Conditions]. Jeddah, KSA: Dar al-Minhaj.

International Association for Islamic Economics [IAIE]. (2009). Economic Solutions from Islamic Finance: Position Statement of the International Association for Islamic Economics. In Islamic Economic Research Center, Issues in the International Financial Crisis from an Islamic Perspective (pp. 267-269). Jeddah, KSA: Scientific Publishing Center, King Abdulaziz University.

International Islamic Fiqh Academy [IIFA]. (2013). Ma'lamat Zayed lil Qawa'id al-Fiqhiyyah wa alUsuliyyah [Zayed Encyclopedia for Fiqh and Jurisprudence Maxims]. Abu Dhabi, UAE: Muassat Zayed Bin Sultan Al-Nahyan lil Amal alKahyriyyah wa al-Insaniyyah.

Ibn Rushd, Muhammad bin Ahmad. (1995). Bidayat al-Mujtahid wa Nihayat al-Muqtasid [The Beginning for the Expert and the End for the Beginner]. Beirut, Lebanon: Dar al-Fikr.

Khan, M. A. (2018). Methodology of Islamic Economics: From Islamic Teachings to Islamic Economics. Turkish Journal of Islamic Economics, $5(1), 35-61$.

Khan, W. M. (1989). Towards an Interest-Free Islamic Economic System. Journal of King Abdulaziz University: Islamic Economics, 1, 3-38.

Majallah al-Ahkam al-'Adliyyah [The Journal of Juristic Rulings: The Ottoman Civil Code]. (1884). Beirut, Lebanon: Al Matba'a Al Adabiyyah.

Mills, P. S., \& Presley, J. R. (1999). Islamic finance: Theory and practice. London, UK: Palgrave Macmillan.

Ministry of Awqaf and Islamic Affairs, State of Kuwait [MAIASK]. (1983). Al-Mawsu'ah alFiqhiyyah al-Kuwaitiyyah [The Kuwait Fiqh Encyclopedia]. Kuwait: Zat al-Salasil.
al-Qaradawi, Y. (1995). Foreword. In M. al-Badri, AlTafakkur: min al-Mushahadah ila al-Shuhud Dirasah Nafsiyyah Islamiyyah [Thinking: From Observation to Surety - An Islamic Psychological Study] (pp. 11-17). Virginia, USA: The International Institute of Islamic Thought.

Reardon, J. (2019). Dialogue on Reform in Mainstream Economics and its Implications for the Islamic Economics Discipline. Journal of King Abdulaziz University: Islamic Economics, 32(2), 61-75.

Robbins, L. (1952). The Theory of Economic Policy in English Classical Political Economy. London, UK: Macmillan.

Samuelson, P. A. (1967). Foreword. In J. de V. Graaff, Theoretical Welfare Economics (pp. vii-viii). Cambridge, UK: Cambridge University Press.

al-Shaibani, Ahmad bin Hanbal. (2001). Musnad alImam Ahmad bin Hanbal. Beirut: Mu'assasah AlRisalah.

al-Sijistani, Abu Dawood Sulaiman bin Ash 'ath. (2009). Sunan Abi Dawood, Beirut: Dar al-Risalah alAalamiyyah.

al-Suwailem, S. (2006 ). Hedging in Islamic Finance (IRTI Occasional Paper No. 10). Jeddah, KSA: Islamic Research and Training Institute, Islamic Development Bank. Retrieved from: https://bit.ly/2OseDi6

Zaman, A. (2013). Logical positivism and Islamic economics. International Journal of Economics, Management and Accounting, 21(2), 1-28.

al-Zarqa, Mustafa Ahmad. (1998). al-Madkhal Al Fiqhi al-'Amm [A General Introduction to Fiqh]. Damascus, Syria: Dar al-Qalam.

Zarqa, Muhammad Anas. (2017). Allocation of Investment in an Islamic Zero-Interest-Rate Economy. Journal of King Abdulaziz University: Islamic Economics, 30(1), 63-72.

al-Zuhaili, W. (2012). Mawsu'ah al-Figh al-Islami wa al-Qadaya al-Mu'asirah [Encyclopedia of Islamic Figh and Contemporary Issues]. Damascus, Syria: Dar al-Fikr. 


\section{Appendix}

\section{Economic Solutions From Islamic Finance:}

\author{
Position Statement of the International Association \\ for Islamic Economics
}

\section{November 2008}

\section{Introduction}

The current global financial crisis has called the attention of world leaders and financial decision makers to seriously consider building a new world financial system. We believe that Islamic economics has much to offer for building a more just and stable market system that encourages real wealth creation and contains market fluctuations.

The current crisis stemmed from excessive indebtedness resting on a relatively small base of equity and real wealth, "the inverted debt pyramid". A significant chunk of finance became merely the selling present for future money. Besides, poor regulations have encouraged over indebtedness.

To build a sustainable system, debt must grow in tandem with real (as opposed to financial) wealth; leverage must be capped by productivity potentials. This allows for real wealth to grow without being hurdled with too heavy debt.

Heavy reliance on debt intensifies economic instability, hence human insecurity, and generates significant negative economy-wide externalities, as painfully exemplified by the present crisis. The collapse of financial institutions inflicts harm upon shareholders, employees, and a host of innocent bystanders. Common economic sense suggests discouraging debt financing and encouraging benign alternatives. However, the exact opposite (e.g. preferential tax treatment of personal and corporate debt) is still the rule.

\section{Riba and Gambling}

The sale of present for future money is based on Riba or interest on loans, which is condemned and prohibited by all religions. It allows debt to multiply independently of real wealth, by mere passage of time. Obviously, this can make debt grow much faster than real wealth. Any big shock can crash such a system of unsustainable debt.
The two basic implications of the prohibition of Riba are: removal of loans from the arena of business finance and the elimination of debt trading. This must be supplemented by instilling more equitable rules for directing a fair share of financing to the poor.

Financial markets have been riddled with risk trading. When pure risk is traded, transactions become indistinguishable from gambling: zero-sum games that create no value. At the macro level, gambling ends up with a negative-sum result, thanks to moral hazard. If risk is cut off from ownership, owners lose interest in protecting the quality of their assets in exchange for higher returns. In the current crisis, financial institutions were able to shed off the risks of their assets, and thus became increasingly reckless in pursuing other objectives.

Gambling, like interest, increases the divergence of financial commitments from real wealth. As the number of bettors rises, total loss when market turns down multiplies. With fictitious derivatives approaching $\$ 600$ trillion, losses may be more than enough to wipe out the real wealth of the losers.

Historically, Islamic finance has been functioning as an integral part of market exchange for centuries. Its recent incarnation into modern institutional structure (banks and financial institutions) is only about 30 years old compared with three centuries of conventional finance. Islamic finance has been struggling to prove itself within the mainstream of interest-based finance. In some aspects, it has succeeded; in others it still has a long way to go. The current crisis proves that Islamic finance is much less influenced by a downturn, as it avoids trading in debt and risk.

\section{Features Of Islamic Finance}

Business financing can be based on profit or revenue sharing where no debt is created. It can also be based on sale for a deferred price, where debt is integrated with real value creation and cannot grow separately. Such a system is free from inverted debt pyramids. The possibility of sharing losses by depositors motivates them to demand greater transparency. Banks are pressed to exercise extra care in risk monitoring.

Risk is effectively integrated with ownership; legitimate risk taking cannot exceed the value of underlying assets; Again, the system is inherently immune to side bets and derivative bubbles. 
Debtors are provided extra time when they become temporarily insolvent, with no increase in the amount of debt. Forbearance has both ethical and economic justification. When markets turn down, decline of collateral value triggers downward spiral as creditors try to protect their positions. However, this would make the market self-destructive, transforming a downturn into a crash. Forbearance relieves debtors, giving them better chances for repayment, while preserving the value of collaterals and preventing market crash.

While, forbearance mitigates the downward pressures on markets, non-interest-based finance mitigates the upward pressures during expansion, as excessive credit extension can turn it into a bubble. Thus, the two principles help contain market fluctuations and maintain reasonable stability, with minimum constraints on growth.

Islamic finance is ultimately governed by ethics and passion for human welfare. Morality is imbedded in the rules, through the prohibition of production and exchange of goods harmful to life and environment.
In addition, contracts that do not carefully balance the interests of both parties and those that make pure risk a subject of trade are not permissible.

Islamic banks have shown resilience in the current crisis. Most are at no risk of becoming bankrupt, and continue to be profitable and serve their clients well. Their experiences may provide lessons for conventional banks.

Islamic finance is a viable paradigm that is based on moral values that are more universally shared than the present system and can potentially be more just and efficient. Principles of Islamic finance are justifiable by rational analysis, economic wisdom and viability. We call on world leaders and decision makers to take them to heart in reformulating a new world financial order.

Note: The above statement was approved by circulation among several members of IAIE, including (from memory): Sami al-Suwailem, Mabid al-Jarhi, M.N. Siddiqi, Monzer Kahf, Fahim Khan, Rodney Wilson, John Presley, Usamah A. Uthman, and M. Anas Zarqa.

Muhammad Anas Zarqa, obtained his LLB (Hon.) from Damascus University in 1960 and his $\mathrm{PhD}$ in economics from the University of Pennsylvania, USA, in 1969. After working for 6 years at the State Planning Commission, Syria, he joined King Abdul Aziz University, Jeddah, in 1976 as an associate professor, and then as a professor at the Centre for Research (now Islamic Economics Institute). In 2000, he joined The International Investor Co. Kuwait, as a consultant and member of its Sharī'ah Group. Since 2009, he is a senior advisor at Shura Sharia Consultancy, Kuwait. His many papers in Arabic and English, published in scholarly journals and conference proceedings, build bridges between economic theory and Islamic figh, in several areas including: microeconomics, allocation, finance, welfare, zakāh and distribution, methodology, theory of policy, and project evaluation. In 1990, he received the Islamic Development Bank Prize in Islamic Economics. He is a member of the International Association of Islamic Economics, U.K., the American Economic Association, and since 2002, the Sharīa ah Criteria Committee of AAOIFI.

E-mail: anaszarka@gmail.com 


\title{
الحواروالأخلاق بين الاقتصيادَيْن الإسلامي والتقليدي
}

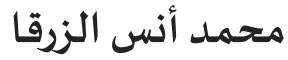 \\ كبير المستشارين، شورى للاستشارات الشرعية ، الكويت
}

المستخلص. إن الحوار بين الاقتصاد الإسلامي والاقتصاد التقليدي (وأقصد باء الشائع في الجامعات

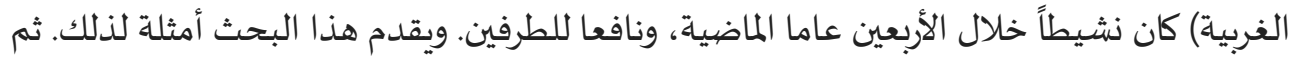
يقوّم الدعوات مؤخرا إلى قطيعة كاملة مع الاقتصاد التقليدي، فيجدها تخالف واقع تعامل الإسلام مع

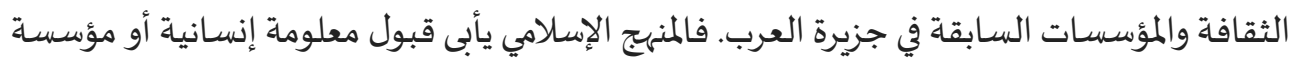

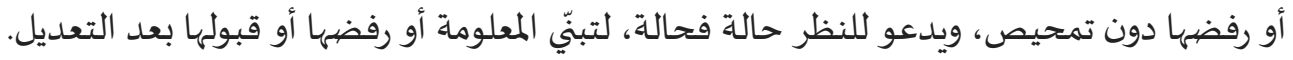

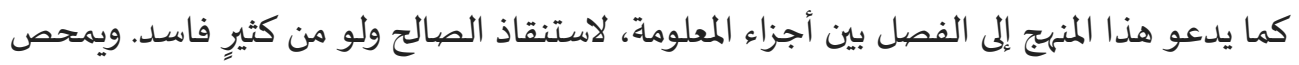

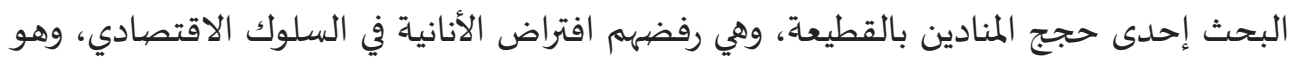
افتراض أساسي في الاقتصاد التقليدي، وبخاصة لدى المدرسة النيوكلاسيكية الحديثة، السائدة في

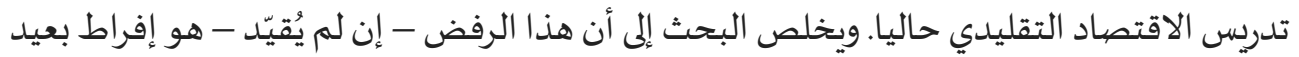
عن الموقف الدقيق للفقه الإسلامي من السلوك الأناني، حيث قَبِل بعضيا،، وكَرِه بعضاه، وحرّم بعضياه،

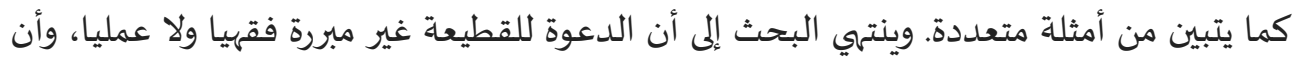
استمرار الحوار مع علم الاقتصاد التقليدي ضهروري ونافع للطرفين، لكناه يحتاج لتصحيح مساره إلى: (أ) إعطاء القطاعات غير الخاضعة للسلوك الأناني ما تستحق من اهتمام حُرمت مناه حتى الآن، رغم

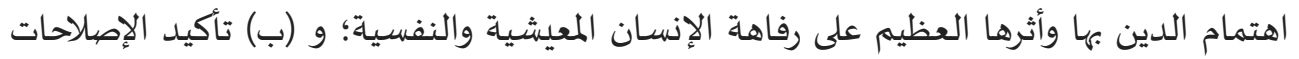

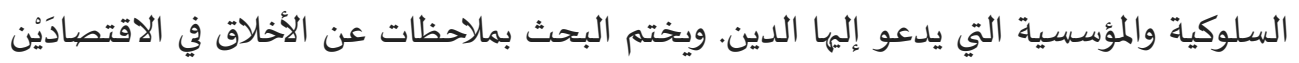

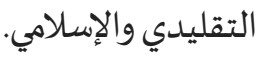

الكلمات الدَّالة: الاقتصاد الإسلامي، المنهجية الاقتصادياة، الأنظمة الاقتصادية المقارنة.

تصنيف P5 P4 B59 B4 35

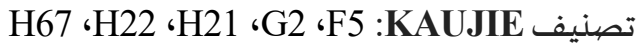

